\title{
Effectiveness of Peer Conflict Resolution Focused Counseling in Promoting Peaceful Behavior among Adolescents
}

\author{
Latipun, S. ${ }^{1}$, Nasir, R. ${ }^{2}$, Zainah, A. Z. ${ }^{2} \&$ Khairudin, R. ${ }^{2}$ \\ ${ }^{1}$ Faculty of Psychology, Muhammadiyah University of Malang, Malang, Indonesia \\ ${ }^{2}$ School of Psychology and Human Development, Faculty of Social Sciences and Humanities, Universiti \\ Kebangsaan Malaysia, Bangi, Selangor, Malaysia \\ Correspondence: Nasir, R., School of Psychology and Human Development, Faculty of Social Sciences and \\ Humanities, Universiti Kebangsaan Malaysia, 43600 UKM Bangi, Selangor, Malaysia. Tel: 60-3-8921-5202. \\ E-mail: rohany@ukm.my
}

Received: June 4, 2012

Accepted: June 16, 2012 Published: July 16, 2012

doi:10.5539/ass.v8n9p8

URL: http://dx.doi.org/10.5539/ass.v8n9p8

\begin{abstract}
The prevalence of conflict among adolescents is very common. At times adolescents use violence to handle conflicts. As such, this problem needs to be addressed. This quasi-experimental study investigated the effectiveness of Peer Conflict Resolution Focused Counseling (PCRC) in promoting peaceful behavior (nonviolence and hostility, conflict resolution strategies, and peaceful friendship) among adolescents. Participants were 80 senior high school students in Mataram, Indonesia. Instruments used were Aggression Questionnaire (AQ) for nonviolence and hostility, Conflict Dynamic Profile (CDP) for conflict resolution strategy, and Human Relation Skill Questionnaire Scale for measuring peaceful friendship. Results showed that the experimental group had significantly higher scores than the control group on peaceful behavior. This implies that counseling, particularly PCRC was effective in promoting peaceful behavior among adolescents.
\end{abstract}

Keywords: counseling, conflict resolution, adolescents, peaceful behavior, nonviolence

\section{Introduction}

Interpersonal conflict is inevitable at all stages in life. It is common to find adolescents experiencing conflicts with their peers (Wheeler, 1994). In Indonesia, conflicts among adolescents are very rampant (Latipun, 2005). Often these adolescents used violence as a way to solve their conflicts (Aryanto, 1992). Studies in America showed that $90 \%$ of adolescents could not solve their conflicts, $25 \%$ preferred using force, violence, and fights to solve their conflicts (Winter et al., 2005).

Promoting peaceful behavior among adolescents can be very difficult. Peaceful behavior represents the attitude, the way, the attempt, and the habit of an individual in promoting, strengthening, improving peaceful feeling towards himself and others from the wider community. The difficulties in promoting and improving peaceful behavior among adolescents are due to both internal (Park and Antonioni, 2007; Yelsma and Yelsma, 1998) and external factors (Johnson and Johnson, 1995). In maintaining peaceful behavior among students, schools frequently apply strict control over the students (Bennett-Johnson, 2004; Page and Hammermeister, 1997). Not many schools use educational approach in solving conflicts among students. Generally, there are three educational approaches commonly used by schools to solve peer conflicts: (1) peace education which is integrated into the school curriculum, (2) constructive problem solving training, and (3) peer mediation and negotiation (Gerstein and Moeschberger, 2003; Johnson and Johnson, 1995; Laursen et al., 2001; Newman et al., 2001; Zhang, 1994).

Conflict resolution programs at schools are rarely put into practice (Theberge and Karan, 2004). Only 8\% of students involved in the programs actually applied what they learned in the program in their daily lives. It was also proven that these programs were not effective. The lack of trust in handling conflicts among students inhibited the effectiveness of the programs (Theberge and Karan, 2004).

In order to promote and improve peaceful behavior, it is necessary to use an appropriate strategy in the form of a constructive conflict resolution. A study done in Indonesia by Latipun (2005) found that most of the school 
principals (97\%) believed that counseling was one of the strategies that was effective in preventing and solving peer conflict. It is also believed that counseling is able to improve the relationship among students and promote peace in the schools. The main concern however, is how to conduct counseling that is effective in solving peer conflicts among adolescents. Latipun (2005) reported that $80 \%$ of school principals in Indonesia assumed that school counselors were responsible for handling students' social and psychological problems. Thus, it was important that school counselors have a proper guideline as to how to resolve conflicts among students. These led to the purpose of this study that was to ascertain the effectiveness of peer conflict resolution counseling using person-centered approach in promoting and improving peaceful behavior among adolescents. The current study also aimed to find out the effectiveness of counseling in improving peaceful behavior based on sex, personality, self-esteem, locus of control, and attachment to parents.

\section{Methods}

\subsection{Research Design}

The current study used the pre-test and post-test research design. The pre-test was conducted a week before the intervention, while the post-test was conducted a week after the intervention. The control group was given PCRC after the post-test. The dependent variable for this study was peaceful behavior while the moderators were self esteem, locus of control, attachment with parents and personality.

\subsection{Participants and Procedures}

A total of 1,373 senior high school students in Mataram, Indonesia went through a pre-selection process to determine their experience of conflicts with their peers. During the first stage of selection, the students had to answer simple questions on the state of their friendship with their peers. Their responses to the questionnaires revealed that 202 students $(14.7 \%)$ were in conflict with peers. The second stage of selection involved personal interview of the 202 students by the researcher. The purpose of the interview was to be doubly certain that the students were really involved in conflicts with their peers and were suitable to participate in the study. The results of the interview indicated that 96 students were suitable and willing to participate in the study. However, 16 students decided to withdraw from participating in the experiment because the timing of the experiment did not fit in with their schedules. Thus, the final number of participants was 80 . The participants were divided into two groups; the experimental group ( 40 students) and the control group ( 40 students).

It is quite common that in one conflict case, three or four students were involved. Therefore, in cases where more than three students were involved in a particular conflict, only two students were found to be more involved in the main problem of the group. These students were then chosen as subjects for this study. The subjects taken as samples were also the conflict pairs with similar sex. The experimental group consisted of 19 conflict cases (17 dyadic conflict cases and 2 triadic conflict cases), while the control group consisted of 18 conflict cases (14 dyadic conflict cases and 4 triadic conflict cases). The characteristic of the subjects are shown in Table 1. (refer Table 1)

Table 1. The subjects' characteristics: age, sex, grade, socio-economic status, and residence

\begin{tabular}{|c|c|c|}
\hline Characteristic & Experimental Group $(\mathrm{N}=40)$ & Control Group $(\mathrm{N}=40)$ \\
\hline 1. age & $\begin{array}{l}16-19 \text { years old } \\
(\mathrm{M}=16.90 ; \mathrm{SD}=.96)\end{array}$ & $\begin{array}{l}16-19 \text { years old } \\
(\mathrm{M}=16.80 ; \mathrm{SD}=.72)\end{array}$ \\
\hline \multicolumn{3}{|l|}{ 2. Sex } \\
\hline Male & 20 students $(25 \%)$ & 20 students $(25 \%)$ \\
\hline Female & 20 students $(25 \%)$ & 20 students $(25 \%)$ \\
\hline \multicolumn{3}{|l|}{ 3. Grade } \\
\hline Grade IV & 15 students $(18.75 \%)$ & 13 students $(16.25 \%)$ \\
\hline Grade V & 21 students $(26.25 \%)$ & 23 students $(28.75 \%)$ \\
\hline Grade VI & 4 students $(5.00 \%)$ & 4 students $(5.00 \%)$ \\
\hline \multicolumn{3}{|l|}{ 4. Social class } \\
\hline Low & 22 students $(27.50 \%)$ & 21 students $(26.25 \%)$ \\
\hline Middle & 18 students $(22.50 \%)$ & 19 students (23.75\%) \\
\hline \multicolumn{3}{|l|}{ 5. Residence } \\
\hline With mother / father only & 8 students $(10.00 \%)$ & 3 students $(3.75 \%)$ \\
\hline With both parents & 32 students $(40.00 \%)$ & 37 students $(46.25 \%)$ \\
\hline
\end{tabular}




\subsection{Counseling Intervention}

The independent variable for this study was the counseling intervention which is Peer Conflict Resolution Focused Counseling (PCRC), given to the experimental group. The experimental group received six sessions (60 minutes for each session) of PCRC which is made up of two sessions of individual counseling and four sessions of paired counseling (where both parties in conflict were counseled together or in negotiation).

The first session was conducted by giving individual counseling to the first, second, or third client. The second session involved in preparing the participants for the negotiation stage which is in the third session. During the third, fourth, fifth and sixth sessions, counseling were conducted in pairs, aiming at reconciling the conflicted participants with the objective of solving their problems. During the process, the counselor also acted as the mediator.

\subsection{Instruments}

Peaceful behavior: Peaceful behavior may be seen from several aspects (Clayton et al., 2001; Gerstein and Moeschberger, 2003; Nelson and Christie, 1995). In the current study, peaceful behavior contained three aspects: (1) nonviolence and hostility, (2) conflict resolution strategies, and (3) peaceful friendship. Nonviolence and hostility constitute peaceful behaviors that prevent and dismiss aggressive behavior towards other people and environment, avoid annoying behavior, provocation, and hostility towards other people. Conflict resolution strategy is peaceful behavior in the form of individual capabilities to solve interpersonal conflicts both constructively and destructively. Peaceful relationship is peaceful behavior in the form of individual capability in building a good relationship with other parties for the sake of strengthening friendship in any condition.

Nonviolence and hostility was measured by Aggression Questionnaire (AQ) (Buss and Perry, 1998). AQ contained items on physical and oral aggressive behavior, anger, and hostility to other people. The instrument contained 24 items with 6 points Likert scale $(1=$ strongly disagree to $6=$ strongly agree). The test done on Indonesians showed that the validity coefficient of correlation between items and the total was $r=0.19$ to 0.47 , $\mathrm{p}<0.001$, with Cronbach alpha $\alpha=0.79$.

Conflict resolution strategy was measured by Conflict Dynamic Profile (CDP) (Davis et al., 2004). CDP contained items on the individual style aspects in conflict resolution: active-constructive, passive-constructive, active-destructive, and passive-destructive. The scale consisted of 13 items with 6-point Likert-type scale ( $1=$ strongly disagree to $6=$ strongly agree). The test done on Indonesians showed that the validity coefficient of correlation between items and the total was $r=0.14$ to $0.44, p<0.05$, with Cronbach alpha $\alpha=0.68$.

Peaceful friendship was measured by Human Relation Skill Questionnaire Scale (FQQ) (Malhi, 2004), consisting of global aspects of individual ability in building relationship with other people. The scale consisted of 15 items with 6-point Likert-type scale ( $1=$ strongly disagree to $6=$ strongly agree). The validity coefficient of correlation between items and its total was $r=0.14$ to $0.44, p<0.05$, with Cronbach alpha $\alpha=0.68$.

Self-esteem was measured by Rosenberg's Self-esteem Scale (SES) (Robinson et al., 1991). The instrument contained 9 items with 6 -point Likert-type scale ( $1=$ strongly disagree to $6=$ strongly agree). The validity coefficient correlation between items and its total was $r=0.31$ to 0.54 , $p<0.01$, with Cronbach alpha $\alpha=0.77$.

Locus of control was measured by Locus of Control Scale (LoCs) (Ghorpade et al., 1999). The instrument consisted of 11 items with 6 -point Likert-type scale $(1=$ strongly disagree to $6=$ strongly agree). The validity coefficient of correlation between items and total was $r=0.19$ to $0.60, p<0.01$, with Cronbach alpha $\alpha=0.76$.

Attachment with parents was measured by Inventory of Parent and Peer Attachment (IPPA) (Armsden and Greenberg, 1987). The instrument consisted of 27 items with 6-point Likert-type scale (1= strongly disagree to $6=$ strongly agree). The validity coefficient of correlation between items and total was $r=0.20$ to $0.73, p<0.01$, and Cronbach alpha was $\alpha=0.91$.

Personality: Two personality factors were measured in the current study: extraversion and agreeableness. The instrument used to measure personality was Bipolar Big-Five Marker (Jensen-Campbell et al., 1996; Saucier, 1994). Each factor was taken from 5 items of unipolar format with 6-point Likert-type response options (1=strongly disagree to $6=$ strongly agree). The validity coefficient of correlation between items and total for extraversion factor instrument was $\mathrm{r}=0.31$ to $0.67, \mathrm{p}<0.01$, and Cronbach alpha was $\alpha=0.79$. Meanwhile, the validity coefficient of correlation between items and the total for agreeableness factor instrument was $r=0.47$ to $0.67, \mathrm{p}<0.01$, and Cronbach alpha was $\alpha=0.85$.

All instruments used in this study were translated into the Indonesian language by using Brislin's back translation technique (Brislin, 1976). 


\section{Results and Discussion}

\subsection{Pre-test Data Analysis}

Result of the $t$-test revealed that there was no significant difference $(t=-0.993, p>0.05)$ on the pre-test score of peaceful behavior between the experimental group $(\mathrm{M}=-0.253, \mathrm{SD}=1.944)$ and the control group $(\mathrm{M}=0.252$, $\mathrm{SD}=2.559$ ). Therefore, both groups were considered homogenous. There was also no significant difference on the three sub-constructs, namely, nonviolence and hostility $(\mathrm{t}=-0.881, \mathrm{p}>0.05)$; conflict resolution strategy $(\mathrm{t}=$ $-0.902, \mathrm{p}>0.05)$; and peaceful friendship $(\mathrm{t}=-0.540, \mathrm{p}>0.05)$. Accordingly, pre-test scores of nonviolence and hostility, conflict resolution strategy, and peaceful friendship sub-constructs between the experimental and control groups were homogenous.

There was also no significant difference in peaceful behavior scores as a whole and for the three sub-constructs, nonviolence and hostility, conflict resolutions strategy and peaceful friendship among male and female adolescents, adolescents with low agreeableness personality and high agreeableness personality, adolescents with low extraversion personality and high extraversion personality. There was also no significant difference on peaceful behavior scores among adolescents with low and high self-esteem, adolescents with external and internal locus of control, as well as subjects with low and high attachment. The results of the statistical analyses on pre-test scores comparing experimental group and control group on peaceful behavior and its sub-constructs are summarized in Table 2. (refer Table 2)

Table 2. T-test on the difference in pre-test score of the dependent variable based on the mediation variable between experimental group and control group

\begin{tabular}{|c|c|c|c|c|c|}
\hline \multirow[t]{2}{*}{ Variable / group } & \multicolumn{5}{|c|}{ Allowed Dependent Variable } \\
\hline & Peaceful behaviour & $\begin{array}{l}\text { Nonviolence } \\
\text { hostility }\end{array}$ & $\begin{array}{l}\text { Conflict } \\
\text { strategy }\end{array}$ & resolution & Peaceful friendship \\
\hline 1. Overall & -0.993 & -0.811 & -0.902 & & -0.504 \\
\hline \multicolumn{6}{|l|}{ 2. Sex } \\
\hline Male & -1.117 & -1.035 & -0.311 & & -1.050 \\
\hline Female & -0.423 & -0.272 & -0.908 & & 0162 \\
\hline \multicolumn{6}{|l|}{ 3. Agreeableness } \\
\hline Low & -1.142 & -0.759 & -1.432 & & -0.172 \\
\hline High & -0.394 & -0.460 & -0.021 & & -0.506 \\
\hline \multicolumn{6}{|l|}{ 4. Extraversion } \\
\hline Low & -0.116 & 0.254 & -0.516 & & 0.022 \\
\hline High & -1.291 & -1.301 & -0.745 & & -0.974 \\
\hline \multicolumn{6}{|l|}{ 5. Self-esteem } \\
\hline Low & -0.375 & -0.339 & -0.531 & & 0.179 \\
\hline High & -1.071 & -0.891 & -0.560 & & -1.280 \\
\hline \multicolumn{6}{|c|}{ 6. Locus of control } \\
\hline External & -0.656 & -0.165 & -0.192 & & -1.300 \\
\hline Internal & -1.011 & -1.670 & -0.932 & & -0.029 \\
\hline 7. Attachment & & & & & 0 \\
\hline Low & -0.166 & -0.692 & -0.244 & & \\
\hline High & -1.229 & -0.396 & -0.716 & & \\
\hline
\end{tabular}

Note: All compared groups were homogeneous $(\mathrm{p}>0.05)$

\subsection{Effectiveness of Peer Conflict Resolution Focused Counseling}

It was found that there was a difference in peaceful behavior between the pre-test scores and post test scores of the experimental group and control group for the main variable of peaceful behavior $(\mathrm{M}=2.431, \mathrm{SD}=0.31)$ and the three sub-constructs of nonviolence and hostility $(\mathrm{M}=8.55, \mathrm{SD}=201)$, conflict resolution strategy $(\mathrm{M}=4.95$, 
$\mathrm{SD}=1.06)$ and peaceful friendship $(\mathrm{M}=4.90, \mathrm{SD}=1.0)$. On the whole, the experimental group had a significantly higher score than the control group.

Based on the results of the data analysis as indicated in Table 3, it can be seen that there was a significant difference between the scores of the experimental and control group for the peaceful behavior variable $(t=7.913$, $\mathrm{p}<0.001)$; nonviolence and hostility $(\mathrm{t}=4.199, \mathrm{p}<0.001)$; conflict resolution strategy $(\mathrm{t}=4.690, \mathrm{p}<0.001)$ and peaceful friendship $(t=3.037, \mathrm{p}<0.01)$. Therefore, it was evident that PCRC was effective in increasing peaceful behavior that includes nonviolence and hostility, conflict resolution strategy and peaceful friendship. (refer to Table 3).

Table 3. T-test results on the effectiveness of PCRC based on moderator variable

\begin{tabular}{|c|c|c|c|c|}
\hline Variable / group & $\begin{array}{l}\text { Dependent Variable } \\
\text { Peaceful behaviour }\end{array}$ & $\begin{array}{l}\text { Nonviolence } \\
\text { hostility }\end{array}$ & $\begin{array}{l}\text { Conflict resolution } \\
\text { strategy }\end{array}$ & Peaceful friendship \\
\hline 1. Overall & $7.913 * * *$ & $4.199 * * *$ & $4.690 * * *$ & $3.037^{* *}$ \\
\hline \multicolumn{5}{|l|}{ 2. Sex } \\
\hline Male & $5.084 * * *$ & $4.469 * * *$ & $2.810^{* *}$ & $2.303 *$ \\
\hline Female & $5.911 * * *$ & $2.170 *$ & $3.762 * * *$ & 1.930 \\
\hline \multicolumn{5}{|l|}{ 3. Agreeableness } \\
\hline Low & $5.911 * * *$ & $2.974 * * *$ & $3.365^{* *}$ & 1.315 \\
\hline High & $5.311 * * *$ & $2.957 * * *$ & $3.531 * * *$ & $2.896^{* *}$ \\
\hline \multicolumn{5}{|l|}{ 4. Extraversion } \\
\hline Low & $4.598 * * *$ & 1.687 & $3.397 * *$ & 1.869 \\
\hline High & $6.696^{* * *}$ & $4.594 * * *$ & $3.511^{* *}$ & $2.408^{*}$ \\
\hline \multicolumn{5}{|l|}{ 5. Self-esteem } \\
\hline Low & $5.899 * * *$ & $2.053 *$ & $4.495 * * *$ & 1.099 \\
\hline High & $4.870 * * *$ & $3.558 * * *$ & 1.742 & $2.982 * *$ \\
\hline \multicolumn{5}{|c|}{ 6. Locus of control } \\
\hline External & $5.389 * * *$ & $2.317^{*}$ & $2.932 * *$ & $2.330^{* *}$ \\
\hline Internal & $4.804 * * *$ & $3.617 * * *$ & $2.803 * *$ & 1.865 \\
\hline \multicolumn{5}{|l|}{ 7. Attachment } \\
\hline Low & $7.016^{* * *}$ & $2.269 *$ & $3.443 * * *$ & $2.612 *$ \\
\hline High & $4.272 * * *$ & $3.427 * *$ & $2.602 *$ & 1.899 \\
\hline
\end{tabular}

Note: ${ }^{*} \mathrm{p}<0.05 .{ }^{* *} \mathrm{p}<0.01 .{ }^{* * *} \mathrm{p}<0.001$.

\subsection{Effectiveness of PCRC in Increasing Peaceful Behavior based on Moderator Variable}

The effectiveness of PCRC in increasing peaceful behavior between the experimental and control groups was analyzed by t-test based on moderator variables, namely, sex, personality, self-esteem, locus of control, and attachment. The t-test analysis result is described in Table 3. (refer Table 3).

The t-test analysis showed that there was a significant difference in peaceful behavior score between the experimental and control groups of male adolescents $(\mathrm{t}=5.084, \mathrm{p}<.001)$ and female adolescents $(\mathrm{t}=5.911, \mathrm{p}<$ $0.001)$. The result of the analysis on nonviolence and hostility sub-construct showed that there was a significant difference between the experimental and control groups of male adolescents $(t=4.469, p<0.001)$ and female adolescents $(\mathrm{t}=2.170, \mathrm{p}<0.05)$. For the conflict resolution strategy sub-construct, there was also a significant difference between male adolescents $(t=2.810, p<0.01)$ and female adolescents $(t=3.762, p<0.001)$. A significant difference was also found on the peaceful friendship sub-construct of male adolescents $(t=2.303, p<$ $0.05)$. However, there was no significant difference in female adolescents $(t=1.930, p>0.05)$.

The analysis of peaceful behavior scores indicated that there was a significant difference between the experimental and control groups of adolescents with low agreeableness personality $(t=5.911, p<0.001)$ and high agreeableness personality $(\mathrm{t}=5.311, \mathrm{p}<0.001)$. For the nonviolence and hostility sub-construct analysis, there was also a significant difference between the experimental and control groups of adolescents with low agreeableness personality $(\mathrm{t}=2.974, \mathrm{p}<0.001)$ and high agreeableness personality $(\mathrm{t}=2.957, \mathrm{p}<0.001)$. A difference was also found on conflict resolution strategy sub-construct; for adolescents with low agreeableness personality, $\mathrm{t}=3.365, \mathrm{p}<0.01$, and the high agreeableness personality, $\mathrm{t}=3.531, \mathrm{p}<0.001$. However, for the peaceful friendship sub-construct, the difference was only found on the high agreeableness personality $(\mathrm{t}=2.896$, $\mathrm{p}<0.01)$, whereas for the low agreeableness personality, there was no significant difference $(\mathrm{t}=1.315, \mathrm{p}>$ $0.05)$. 
The result of the analysis also showed a significant difference on peaceful behavior scores between experimental and control groups for the subjects with both low extraversion personality $(\mathrm{t}=4.598, \mathrm{p}<0.001)$ and high extraversion personality $(t=6.696, p<0.001)$. The analysis for nonviolence sub-construct and hostility scores showed that there was a significant difference for adolescents with high extraversion personality $(t=4.594, p<$ $0.001)$ but no significant difference for adolescents with low extraversion personality $(t=1.687, p>0.05)$. A significant difference also existed in conflict resolution sub-construct between experimental and control groups of adolescents with both low extraversion personality $(\mathrm{t}=3.397, \mathrm{p}<0.01)$ and high extraversion personality $(\mathrm{t}=$ $3.511, \mathrm{p}<0.001)$. For peaceful friendship sub-construct, a significant difference was only found in the subjects with high extraversion personality $(t=2.408, \mathrm{p}<0.05)$ but not in the adolescence with low extraversion personality $(\mathrm{t}=1.869, \mathrm{p}>0.05)$.

A significant difference of peaceful behavior scores was found between the experimental and control groups for the subjects with low self esteem $(t=5.899, p<0.001)$ and subjects with high self esteem $(t=4.870, p<0.001)$. This significant difference was also found in nonviolence and hostility sub-construct for adolescents with both low self esteem $(\mathrm{t}=2.053, \mathrm{p}<0.05)$ and high self esteem $(\mathrm{t}=3.558, \mathrm{p}<0.001)$. Nevertheless, a significant difference on conflict resolution strategy sub-construct was found only in subjects with low self esteem $(\mathrm{t}=$ $4.495, \mathrm{p}<0.001)$ but not in subjects with high self esteem $(\mathrm{t}=1.742, \mathrm{p}>0.05)$. There was no significant difference on sub-construct peaceful friendship mean scores in subjects with low self esteem $(t=1.099, p>0.05)$ but there was a significant difference in subjects with high self esteem $(t=2.982, p<0.01)$.

The scores on peaceful behavior between the experimental and control groups among adolescents with external locus of control $(\mathrm{t}=5.389, \mathrm{p}<0.001)$ and internal locus of control $(\mathrm{t}=4.804, \mathrm{p}<0.001)$ were significantly different. The result of analysis also showed a significant difference in scores of nonviolence and hostility sub-construct between adolescents with external locus of control $(t=2.317, p<0.05)$ and with internal locus of control $(t=3.617, p<0.001)$. A similar result was also found on conflict resolution strategy for both subjects with external locus of control $(t=2.932, p<0.01)$ and internal locus of control $(t=2.803, p<0.01)$. While for peaceful friendship sub-construct, a significant difference was only found in adolescents with external locus of control $(\mathrm{t}=2.330, \mathrm{p}<0.05)$ but was not found in those with internal locus of control $(\mathrm{t}=1.865, \mathrm{p}>0.05)$.

T-test analysis revealed that there was a significant difference in peaceful behavior mean scores between experimental and control groups for subjects with less attachment to their parents $(t=7.016, p<0.001)$ and those with high attachment to their parents $(\mathrm{t}=4.272, \mathrm{p}<0.001)$. The results of the analysis also showed that there was a significant difference in the mean scores of nonviolence and hostility sub-construct $(t=2.269, p<$ $0.05)$; conflict resolution strategy $(t=3.443, p<0.001)$ and peaceful friendship $(t=2.612, p<0.05)$ for subjects with low attachment to their parents. Meanwhile, for the subjects with high attachment to their parents, there was a significant difference on nonviolence and hostility sub-construct $(t=3.427, p<0.001)$ and conflict resolution strategy sub-construct $(\mathrm{t}=2.602, \mathrm{p}<0.05)$, but there was no significant difference on peaceful friendship $(\mathrm{t}=$ $1.899, \mathrm{p}>0.05)$.

The results of the current study revealed that PCRC was effective in improving peaceful behavior among adolescents. It was also effective in improving nonviolence and hostility, conflict resolution strategy, and peaceful friendship among adolescents in this study. There are two implications of the current findings. Firstly, peaceful behavior could be raised to a higher level that is a shift from less peaceful behaviors to more peaceful ones. Secondly, peer conflict resolution focused counseling as an intervention technique had was shown to be effective in improving peaceful behavior among adolescents.

The findings of this study further support Person-Centered Theory, which suggests that the aim of counseling is to help clients to experience congruence which is a psychological state whereby a person does not experience inner conflicts and a more harmonious relationship with other people. A person who is congruent will behave more peacefully towards other people (Rogers, 1961; Rogers, 1962; Rogers, 1963).

Studies on Turkish (Guneri and Coban, 2004), and Brazilian adolescents (Freire et al., 2005), as well as on American children (Cochran et al., 2002) proved that psychological intervention was effective in improving peaceful behavior. A study by Barret-Lennard (1998) which applied Person-Centered Approach in a conflict resolution workshop proved that conflicting groups tended to accept and communicate better with each other after sharing their problems. A number of interventions such as counseling, conflict resolution training, and empathetic communication were effective in changing behaviors; enable the subjects to understand more about other people, to resolve their own problems constructively, and to develop peaceful behavior towards other people. 
The results of this study support previous experimental studies (Shechtman and Nachshol, 1996), meta-analysis (Clayton et al., 2001; Prout and DeMartino, 1986; Wilson and Lipsey. 2007), and indirect experimental study on students (Orpinas and Horne, 2004). Those studies have concluded that school-based interventions lessen aggressive attitude and behavior, increase adolescents' ability in resolving interpersonal conflicts, and improve interpersonal relationship among them. In other words, intervention leads to peaceful behavior among adolescents.

Based on the results of the current study, Person-Centered Approach which became the basis of PCRC contributed to the effectiveness of the intervention. The Person-Centered Approach emphasized that therapeutic condition was necessary in solving clients' problems. The counselor's congruence, positive regard, genuineness and empathetic understanding acted as the therapeutic condition of the counseling process. The therapeutic condition allowed catharsis, emotional freedom, openness and willingness to solve problems. Those therapeutic factors were available during the counseling process (Bloch et al., 1979; Lampropoulus, 2001; Rogers, 2007). Rogers emphasized that the therapeutic condition was sufficient and necessary in a counseling process, as it promotes positive change in client's behavior (Rogers, 2007).

Teachers may also be involved in the intervention process provided that they are trained in conflict resolution techniques. A study on teachers revealed that training for teachers on a model of constructive conflict resolution and cooperative learning was effective in increasing social behaviors, reducing misbehaving actions, improving positive attitudes towards other people, and strengthening interpersonal relationships among students (Zhang, 1994).

Generally, PCRC was effective in improving overall peaceful behaviors. The intervention was also effective for specific behaviors such as nonviolence and hostility, conflict resolution strategies and peaceful friendship in both male and female adolescents, adolescents with high and low personality extraversion, adolescents with high or low self-esteem, adolescents with external or internal locus of control, and adolescents with high or low attachment to their parents.

However, the current study found that PCRC was ineffective in increasing peaceful friendship among female adolescents. Boys and girls had different natural tendencies. For girls, friendship is their top priority while boys tend to be less intimate in their friendship. Nonetheless, when a conflict occurred among the same sex, girls are more deeply affected by their conflicts than the boys because the conflicts become personalized due to emotional reasons. For this reason, PCRC is unlikely to be advantageous or beneficial for girls (Kenny et al., 2005).

PCRC was also ineffective in increasing peaceful friendship for adolescents with low agreeableness, low extraversion, low self-esteem, internal locus of control, and high attachment. The peaceful friendship behavior was not only personal but also involves other people/friends. An adolescent might experience conflicts several times during the same phase of his life (Wheeler, 1994; Winter et al., 2005). Based on their studies, Winter et al. (2005) and Wheeler (1994) concluded that it was insufficient to conduct one counseling service to adolescents with high tendencies for conflicts. In other words they needed more intensive and probably more interventions in order to promote or increase peaceful behavior.

The current study also found that PCRC was also ineffective in improving conflict resolution among adolescents with high self-esteem. Individuals with high self-esteem might experience psychological problems due to their egoistic tendencies (Baumeister, 1996). Based on studies by Baumeister et al. (1996), together with Bushman and Baumeister (1998), individuals tended to defend their self appraisals consistently; to avoid self changing, and to perceive that they do not need any help from other people. Furthermore, when they came into their ego, they tended to react emotionally, perceiving that they were doing something right.

\section{Conclusion}

The results of the study supported previous studies. Counseling intervention was effective in reducing aggression and conflicts among students, in raising creativity to cope with conflict, and in strengthening social relationship. It can be concluded that PCRC is an alternative intervention to conflicts among adolescents.

\section{References}

Armsden, G. C., \& Greenberg, M. T. (1987). The inventory of parent and peer attachment: individual differences and their relationship to psychological well-being in adolescence. Journal of Youth and Adolescence, 16(5), 427-454. http://dx.doi.org/10.1007/BF02202939

Aryanto, A. (1992). An exploration of Reasoned Action and Planned Behaviour theories on behaviour in the quarrels among SLTA and STM university students in Jakarta (Tinjauan teori Reasoned Action dan Planned 
Behaviour mengenai tingkah laku terlibat dalam perkelahian pada siswa SLTA dan STM di Jakarta). Masters Thesis, Fakultas Psikologi, Universitas Indonesia Jakarta.

Barrett-Lennard, G. T. (1998). Carl Rogers' helping system: Journey and substance. London: Sage Publications.

Baumeister, R. F., Smart, L., \& Boden, J. M. (1996). Relation of threatened egotism to violence and aggression: The dark side of high self-esteem. Psychological Review, 103(1), 5-33. http://dx.doi.org/10.1037/0033-295X.103.1.5

Bennett-Johnson, E. (2004). The root of school violence: Cause and recommendation for a plan of action. College Student Journal, 38(2). Retrieved from http://findarticle.com/p/articles/mi_mFCR/

Bloch, S., Reibstein, J., Crouch, E., Holroyd, P., \& Themen, J. (1979). A method for the study of therapeutic factors in group psychotherapy. British Journal of Psychiatry, 134(3), 257-263. http://dx.doi.org/10.1192/bjp.134.3.257

Brislin, R. W. (1976). Comparative research methodology: Cross-cultural study. International Journal of Psychology, 11(3), 215-229. http://dx.doi.org/10.1080/00207597608247359

Bushman, B. J., \& Baumeister R. F. (1998). Threatened egotism, narcissism, self-esteem, and direct and displaced aggression: Does self-love of self-hate lead to violence. Journal of Personality and Social Psychology, 75(1), 219-229. http://dx.doi.org/10.1037/0022-3514.75.1.219

Buss, A. H., \& Perry, M. (1992). The Aggression Questionnaire. Journal of Personality and Social Psychology, 63, 452-459. http://dx.doi.org/10.1037/0022-3514.63.3.452

Clayton, C. J., Ballif-Spanvill, B., \& Hunsaker, M. D. (2001). Preventing violence and teaching peace: A review of promising and effective antiviolence, conflict-resolution, and peace program for elementary school children. Applied and Preventive Psychology, 10, 1-35. http://dx.doi.org/10.1016/s0962-1849(05)80030-7

Cochran, J. L., Cochran, N. H., \& Hatch, E. J. (2002). Empathetic communication for conflict resolution among children. The Person-Centered Journal, 9(2), 110-118.

Davis, M. H., Capabianco, S., \& Kraus, L. A. (2004). Measuring conflict-related behaviours: Reliability and validity evidence regarding the conflict dynamics profile. Educational \& Psychological Measurement, 64(4), 707-731. http://dx.doi.org/10.1177/0013164404263878

Freire, E. S., Koller, S. H., Piason, A., \& Silva, R. B. (2005). Person-Centered Therapy with impoverished, maltreated, and neglected children and adolescents in Brazil. Journal of Mental Health Counselling, 27(3), 225. Retrieved 20 November, 2006, from http://www.questia.com/ PM.qst?a

Gerstein, L. H., \& Moeschberger, S. L. (2003). Building culture of peace: An urgent task for counselling

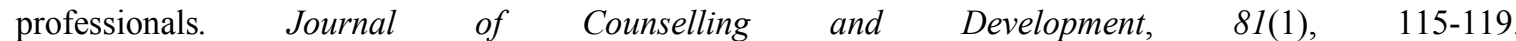
http://dx.doi.org/10.1002/j.1556-6678.2003.tb00233.x

Ghorpade, J., Hattrup, K., \& Lackritz, J. R. (1999). The use of personality in cross-cultural research: a test of three personality scale across two countries. Journal of Applied Psychology, 84(5), 670-679. http://dx.doi.org/10.1037/0021-9010.84.5.670

Guneri, Y., \& Coban, R. (2004). The effect of conflict resolution training on Turkish elementary school students: A quasi-experimental investigation. International Journal for the Advancement of Counselling, 26(2), 109-124. http://dx.doi.org/10.1023/B:ADCO.0000027425.24225.87

Jensen-Campbell, L. A., Graziano, W. G., \& Hair, E. C. (1996). Personality and relationship as moderators of interpersonal conflict in adolescence. Merrill-Palmer Quarterly, 42(1), 148-164.

Johnson, D. W., \& Johnson, R. T. (1995). Teaching student to be peacemaker: Results of five years of research. Peace and Conflict: Journal of Peace Psychology, 4, 438. http://dx.doi.org/10.1207/s15327949pac0104_8

Kenny, M., McEachern, A. G., \& Aluede, O. (2005). Female bullying, prevention and counselling intervention. Journal of Social Sciences, 8(Special Issue), 13-19.

Kirschenbaum, H. (2004). Carl Rogers's life and work an assessment on the 100th anniversary of his birth. Journal of Counselling and Development, 82(1), 116. http://dx.doi.org/10.1002/j.1556-6678.2004.tb00293.x

Lampropoulus, G. K. (2001). Common processes of change in psychotherapy and seven other social interactions. British Journal of Guidance and Counselling, 29(1), 21-33. http://dx.doi.org/10.1080/03069880020019356

Latipun. (2005). School management of conflicts among adolescence (Penanganan sekolah terhadap konflik antar remaja). Research report of Universitas Muhammadiyah Malang. 
Laursen, B., Finkelstein, B. D., \& Betts, N. T. (2001). A developmental meta-analysis of peer conflict resolution. Developmental Review, 21, 423-449. http://dx.doi.org/10.1006/drev.2000.0531

Malhi, R. S. (2004). Enhancing personal quality. Kuala Lumpur: TQM Consultants SDN. Bhd.

Nelson, L. L., \& Christie, D. J. (1995). Peace in the psychology curriculum: moving from assimilation to accommodation. Peace and Conflict: Journal of Peace Psychology, 1(2), 161-178. http://dx.doi.org/10.1207/s15327949pac0102_5

Newman, R. S., Murray, B., \& Lussier, C. (2001). Confrontation with aggressive peers at school: Student' reluctance to seek help from the teacher. Journal of Educational Psychology, 93(2), 398-410. http://dx.doi.org/10.1037/0022-0663.93.2.398

Orpinas, P., \& Horne, A. M. (2004). A teacher-focused approach to prevent and reduce students' aggressive behaviour: the GREAT teacher program. American Journal of Preventive Medicine, 26(1S), 29-38.

Page, R. M., \& Hammermeister, J. (1997). Weapon-carrying and youth violence. Adolescence, 32(127), 505-513.

Park, H., \& Antonioni, D. (2007). Personality, reciprocity, and strength of conflict resolution strategies. Journal of Research in Personality, 41(1), 110-125. http://dx.doi.org/10.1016/j.jrp.2006.03.003

Prout, H. T., \& DeMartino, R. A. (1986). A Meta-analysis of school-based studies of psychotherapy. Journal of School Psychology, 24, 285-292. http://dx.doi.org/10.1016/0022-4405(86)90061-0

Robinson, J. P., Shaver, P. R., \& Wrightsmen, L. S. (1991). Measures of personality and social psychological attitudes. San Diego: Academic Press.

Rogers, C. R. (1961). On becoming a person. Boston: Houghton Mifflin Co.

Rogers, C. R. (1962). The Interpersonal relationship: the core guidance. Harvard Educational Review, 32(2), 416-429.

Rogers, C. R. (1963). The concept of the fully functioning person. Psychotherapy: Theory, Research, Practice, l(1), 17-26. http://dx.doi.org/10.1037/h0088567

Rogers, C. R. (1987). The understanding theory: drawn from experience with individual and group. Counselling and Values, 32(1), 38-46. http://dx.doi.org/10.1002/j.2161-007X.1987.tb00689.x

Rogers, C. R. (2007). The necessary and sufficient conditions of therapeutic personality change. Psychotherapy: Theory, Research, Practice, Training, 44(3), 240-248 (reprint Journal of Consulting Psychology, 21, 95-103). http://dx.doi.org/10.1037/0033-3204.44.3.240

Saucier, G. (1994). Mini-marker: a brief version of Goldberg's unipolar Big-Five Markers. Journal of Personality Assessment, 63(3), 506-516. http://dx.doi.org/10.1207/s15327752jpa6303_8

Shechtman, Z., \& Nachshol, R. (1996). A school-based intervention to reduce aggressive behaviour in maladjusted adolescents. Journal of Applied Developmental Psychology, 17, 535-552. http://dx.doi.org/10.1016/S0193-3973(96)900115-5

Theberge, S. K., \& Karan, O. C. (2004). Six factors inhibiting the use of peer mediation in a Junior High School. Professional School Counselling, 7(4), 283-290.

Wheeler, E. J. (1994). Peer conflict in the classroom: drawing implications from research.

Wilson, S. J., \& Lipsey, M. W. (2007). School-based interventions for aggressive and disruptive behaviour. American Journal of Preventive Medicine, 33, 131-143. http://dx.doi.org/10.1016/j.amepre.2007.04.011

Winter, D. G. (1993). Power, affiliation, and war: three tests of a motivational model. Journal of Personality and Social Psychology, 65(3), 532-545. http://dx.doi.org/10.1037/0022-3514.65.3.532

Winter, J., Neal, J. C., \& Waner, K. K. (2005). Student teams learning to cope with conflict. The Delta Pi Epsilon Journal, 85(2), 67-74.

Yelsma, P., \& Yelsma, J. (1998). Self-esteem and social respect within the high school. The Journal of Social Psychology, 138(4), 431-441. http://dx.doi.org/10.1080/00224549809600398

Zhang, Q. (1994). An intervention model of constructive conflict resolution and cooperative learning. Journal of Social Issues, 50(1), 99-116. http://dx.doi.org/10.1111/j.1540-4560.1994.tb02400.x 